\title{
The Nature of Iranian Petroleum Contracts in Upstream Section
}

\author{
Mahdi Haddadi \\ Faculty of Law, Farabi Campus, University of Tehran, Iran \\ E-mail address: Mhaddady@ut.ac.ir
}

\begin{abstract}
Petroleum contracts are an important and sensitive issue in Iranian petroleum industry. Monitoring on petroleum contracts especially in upstream section is too important due to length of term and high financial volume. After Islamic revolution in Iran, a challenging discussion between the Parliament and Government was the supervision and approval of petroleum contracts by Parliament. Article 77 of Iranian Constitutional Law permits the Parliament to monitor on international agreements directly. Therefore, determining the nature of petroleum contracts would highly impact on this kind of supervision by the Parliament. However, Parliament can monitor on these contract properly by using its authorities mentioned in the Constitutional Law and by codification or modifying relevant laws including the Law to Modify Petroleum Law.
\end{abstract}

Keywords: Petroleum contract; upstream section; international contracts; Parliament's supervision; Constitutional Law; treaty

\section{INTRODUCTION}

Expansion of expectations from the government and the incapability of private sector have caused the entrance of the government to areas run already by private sector. Among such areas one can point out running big industries or exploiting mines and petroleum and gas resources. In some countries, these sections are owned by public sector or government. In Iran, petroleum and gas resources and their related industries especially upstream section is one of the most important areas which is nationalized and owned publicly. On this basis, before Islamic revolution based on Mines Law approved in 1957, all mines were categorized into three groups. The third group consisted of all petroleum, gas and radioactive materials which owned by the government and the lands where these mines are located should be sold to government in order to be exploited.

After Islamic revolution, Constitutional Law (articles 44 and 45) nationalized all mines which should be used in the interest of the people by Islamic administration. Additionally, article 2 of Petroleum Law (1987) has considered petroleum resources as public assets. To this end, general polices of article 44 of the Constitutional Law has considered petroleum resources as national ones and developmental policies by private sector are forbidden in this section. 
Before nationalization, running petroleum resources was through concession while after nationalization it was replaced by contractual mood. Contractual mood is an exclusive method in running petroleum resources by government.

High volume of financial flow in petroleum contracts (for instance, 22 buyback contracts valued about 39 \$ billion were concluded between 1995 and 2003) and their length on the one hand and the fact that over $50 \%$ of domestic public budget and over $90 \%$ of imported foreign currencies are supplied through petroleum industry (Parliament Research Center, 2007) on the other hand, show the importance of petroleum industry for Iran.

The major risk of petroleum contracts in upstream section is due to exploration, development and production. However, petroleum sale contracts are less faced with such problems since they are based on daily basis prices. Monitoring on upstream contracts is too important due to their costs and length. If Iranian petroleum contracts are considered as international agreements and treaties, they can be directly supervised by the Parliament in accordance with article 77 of the Constitutional Law.

Therefore, it is important to study some issues: which authorities are authorized to conclude such contracts? Who are contracted parties? What is the nature of such contracts in terms of administrative or private aspects? What is the international criterion for petroleum contracts? What are the formats of petroleum contracts in upstream section?

\section{IRANIAN COMPETENT ENTITIES TO CONCLUDE PETROLEUM CONTRACTS}

As mentioned in introduction, petroleum resources are owned by government. Before Islamic revolution and based on article 2 and article 3(1 \& 2) of Iranian Petroleum Law (1974), petroleum resources were owned by National Iranian Petroleum Company (NIOC). On this basis, NIOC had two tasks: exercise the right of ownership by Iranian nation over petroleum resources in terms of petroleum exploration, development, production and exploitations and distribution (article 3(1)); and, negotiation with both Iranian and foreign nationals for explorative and developmental operations in a contractual basis (article 3(2)).

After Islamic revolution and by ratifying the bill on establishing Petroleum Ministry in Revolution Council, the relevant ministry was shaped. Afterwards, Acta Jure Imperii tasks on petroleum industry assigned to Petroleum Ministry and its relevant deputies while technical tasks in upstream section were designated to NIOC and its affiliated firms (Parliament Research Center).

Based on article 1 of supplementary bill on the law of establishing Petroleum Ministry, Acta Jure Imperii tasks of Petroleum Ministry include protecting petroleum reservoirs (paragraph 1), supervision on petroleum affairs (paragraph 4), policymaking (paragraph 6), planning (paragraph 8) and designing petroleum organizational charter (paragraph 11).

Administrative and operational tasks especially in concluding petroleum contracts should be covered by NIOC since by approving Petroleum Ministry Law, only article 3(1) of petroleum Law (1974) was nullified while article 3(2) was remained.

This was the main procedure in Petroleum Ministry and on this basis, petroleum contracts are assigned to NIOC. In 1987 and by approving new Petroleum Law, Petroleum Ministry is also allowed to conclude petroleum contracts. Since Petroleum Law (1974) was not nullified clearly, the benchmark for Petroleum Ministry is the procedure used before 1987. Upon approval of the Law to Modify Petroleum Law in 2011, Petroleum Law (1974) was clearly nullified. In article 2 of the Law to Modify Petroleum Law (2011), Petroleum Ministry 
has the right of governance and public ownership on petroleum resources on behalf of Islamic Republic of Iran. Additionally, in article 16(1), competent authorities to conclude petroleum contracts are both Petroleum Ministry and NIOC. Therefore, competent authorities to conclude petroleum contracts in upstream section are Petroleum Ministry and NIOC.

\section{FOREIGN PARTIES OF IRANIAN PETROLEUM CONTRACTS IN UPSTREAM SECTION}

Another raised question is that "to which persons are Iranian competent authorities allowed to conclude petroleum contracts in upstream section and is foreign investment possible in this section?

In accordance with all laws pre and post Islamic revolution, domestic people are allowed contract parties. Before Islamic revolution and respective to article 3 of Petroleum Law (1974) in petroleum upstream section, foreigners were only able to operate as contractors. Upon Islamic revolution and based on article 6 of Petroleum Law (1987), foreign investment was forbidden and only those contracts with foreigners were allowed which required no foreign investment. However, such limitations were reduced to somehow in annual budgetary laws. Upon approval Law on encouraging and supporting foreign investment in 2002, the limitations on foreign investments were removed and the ground was paved for foreign investment based on contractual methods which required investments.

Another question was that whether foreign governments can enter into upstream operations or not. According to article 4 of the law on encouraging and supporting foreign investment, investments by foreign governments are possible by the approval of the Parliament.

\section{PETROLEUM CONTRACTS IN UPSTREAM SECTION: INTERNATIONAL TREATY OR AGREEMENT?}

Although many people use title of international contract in exchange of international treaty and although title doesn't have so impact on the nature of a agreement in international law, one can distinguish international contract and treaty. Treaty is a written international agreement among states (or international organizations) governed by international law. This definition has a separated identity of definition of Convention on the Law of Treaties (1969). In other words, it has found a common situation now (Klabbers, 1998). From a legal perspective, subject of agreement for example commercial subjects has no impact on the nature of the treaty (Mir Abbassi, 1997). These agreements are called treaty - contract. If the same governments conclude an agreement and govern it by domestic laws instead of international laws, it will not be considered as a treaty. Although all parties of an agreement should international persons so that the document can be considered as treaty, it does not mean that all agreements to which the parties are international persons can be considered as treaty and covered by international laws (even though this is a strong statistic) (Degan, 1997). Such agreements among governments that are out of international law circle are called as international private contracts or international contracts under domestic laws.

Agreements among governmental institutions like ministries, agencies and organizations as parts of government are also considered as international treaties. These agreements are called agreements in simplified form or executive agreements. According to 
international law, these agreements obliged the governments (not simply the relevant governmental organization) since governmental institutions like Petroleum Ministry are a part of government and lack international legal personality in international law. On this basis and in the framework of international responsibility, their conducts is attributed to state (Fitzmaurice, 2005). On the other hand, international law system has assigned the right of determining competent agencies and authorities to conclude international agreements to internal legal systems. Therefore, any state can decide whether governmental agencies have the right to conclude agreement with foreign governmental agencies without the permission of competent authorities like Parliament or not (Haddadi, 2002).

Considering the diversity of organs through which governmental tasks including commercial ones are performed, it is necessary to distinguish between a governmental agency, institute or organization which is considered as a part of government and can oblige government and an organ with separated legal personality which cannot oblige government. Governmental companies are among these entities which can conduct commercial and investment activities based on domestic laws and their own articles of constitution, they may conclude contracts with other governments or foreign governmental companies. Such contracts are not considered as treaty and are not governed by international law (Carreau, 1981). International contracts are contracts in which there are a foreign element such as foreign parties or the location of conclusion and enforcement of the contract is in another country. Therefore, the contract would relate to more than one national legal system. In the meantime, domestic laws govern such contracts (Shiravi, 2010).

Concerning above points, if petroleum contracts in upstream section are concluded by government or Petroleum Ministry with another government or foreign governmental agency, they will be international treaties, unless the parties clearly bring them out of governed by international law and governed by domestic laws. Likewise, the contract by government or Petroleum Ministry with foreign private or public companies, they are international contracts not international treaty. Petroleum contracts in upstream section concluded between NIOC and foreign public or private companies or even with a foreign governmental organization are also international contracts.

\section{THE NATURE OF INTERNATIONAL PETROLEUM CONTRACTS OF GOVERNMENTAL AGENCIES WITH FOREIGN COMPANIES}

There are disagreements concerning the nature of contracts (i.e. petroleum or foreign investment contracts) between government or public and governmental agencies, that are responsible for Acta Jure Imperii affairs, and foreign private parties. Although investigating such disagreements is not covered by this research, it seems despite the fact that the operations by private sector especially multi-national companies in petroleum upstream section are done under commercial contracts, but due to government's ownership on petroleum resources in most countries and its intervention as the representative of public not an ordinary merchant on the one hand, and the strategic role of petroleum in economy and policy of producing countries on the other hand, prejudice on the private nature of such contracts is far from reality (Mostafavi, 2008).

Comparative studies in legal systems, international law, international arbitration awards especially Amin Oil award (1982) and the opinions by authors and connoisseurs indicate that petroleum contracts in upstream section are considered as public or governmental contracts like other economic development contracts (El - Khosheri, 1986). It is concept taken from 
French Laws and means unilateral authority of governments to mitigate public service contracts.

Iranian practical procedure upon Petroleum Law (1974) has been that it considers petroleum contracts as private and NIOC has accepted mitigation in petroleum contracts only based on the conditions mentioned in the contract. However, in line with the principle of nations' sovereignty on their own natural resources, international law has assigned the right of governance to countries which depends on compensating the damages of other party (Resolution 3201, 1803, 626, UN General Assembly).

\section{THE WAY OF CONTRIBUTION AND FOREIGN INVESTMENT IN PETROLEUM UPSTREAM SECTION}

Foreign investment is to use foreign capitals in activities in which the risk of return of investment and interests are bore by investor. It is categorized in two main methods by Iranian foreign investment:

a. Legal contribution (direct investment): it means to invest a part of foreign investment in an existing or new Iranian company. The amount of shares by foreign investor in Iranian company is not limited and the investor can play role in managing the company in terms of his shares.

b. Contractual arrangements: it refers to a set of methods by which foreign capital is used only based on mutual agreements. No right is created for foreign investor due to his direct contribution in capital of Iranian company; rather, it is only depended on mutual contractual arrangements. Foreign investment is executable in all section under the framework of contractual arrangements. Investment return and interests in such investments are acquired through the performance of investment plan and without relying to guarantees by government, banks or governmental companies. Therefore, contractual arrangements mean types of financing methods in the framework of civil contribution methods, buyback and BOT. In sections that are governed by government such as petroleum industry, foreign investment is only performable within contractual arrangements.

Before Islamic revolution in Iran, concession was the usual method of contribution by foreign companies in upstream section. On this basis, the government was granted the exclusive right of exploration, production, marketing and sales and assigned it to an international petroleum company and on this basis it was owned the petroleum. The petroleum company was also committed to pay royalty interest and tax to government (Fayazbakhsh, 2010). Upon the petroleum nationalization and due to historic grounds, the way of granting concession changed to consortium contracts and contribution in production. Although by approving petroleum law (1974), the way of concession was cancelled, but the forecasted solution in petroleum laws namely risk-taking service contracts was a kind of modern concession with a modern structure.

After Islamic revolution, considerable limitations were devised by the Constitution Law concerning the contribution of private sector in general and foreign investors in particular in economic activities. These limitations led into two decades of buyback contracts as the most 
important mechanism to develop petroleum fields in Iran and during this period, numerous buyback contracts are concluded between NIOC and foreign petroleum companies (Shiravi and Ebrahimi, 2006). Although the law on encouraging and supporting foreign investment and article $4(\mathrm{~b})$ of the $4^{\text {th }}$ economic, social and cultural development plan has paved the ground for concluding types of contracts, but petroleum industry has not waved buyback contracts.

Buyback contract is a contractual arrangement by which foreign petroleum company supplies all costs on investment including equipment, installing, commissioning as well as all costs related to manpower and operational costs to develop petroleum fields. After production reaches the level specified in the contract, all equipment is transferred to NIOC and NIOC agrees to pay all costs, wages and profits of the contractor through petroleum direct sale from petroleum field within agreed period (5 to 8 years) (Saber, 2010).

Close competition in petroleum and gas as well as the emergence of new petroleum powers in recent two decades and providing new model of petroleum contracts by regional rivals have all enforced Iran to revise its petroleum contracts. Investigating new petroleum contracts show that these contracts are based on buyback while their model is taken from successful Iraqi service contracts. So, a combined contract by buyback and Iraqi service contracts is shaped.

\section{CONCLUSIONS}

In present paper, the nature of Iranian petroleum contracts is studied. The reason is that based on Iranian Constitutional Law, Iranian international agreements should be ratified by Parliament. Supervision and approval by Parliament include contracts between Iranian government and other governments as well as contracts between Petroleum Ministry and foreign ministries, institutes or organizations since as mentioned, they are considered as international treaties and are governed by international laws. Therefore, they should be approved by Parliament in accordance with article 77 of the Constitutional Law. In cases that the parties determine domestic regulations to govern their contracts, they are not considered as treaty; rather they will be seen as private international contract. However, contracts by government and Petroleum Ministry with foreign governmental or private companies as well as contracts by NIOC with foreign petroleum companies are not covered by article 77 of the Constitutional Law and are not monitored by Parliament directly. Of course, Iranian Parliament can monitor petroleum contracts in another way. It is an informative monitoring method. On this basis, the Parliament should be informed of the text, financial volume, commitments and conditions mentioned in petroleum contracts. Considering articles 76, 88 and 89 of the Constitutional Law, Parliament can be aware of petroleum contracts through such tools such as investigation of petroleum contracts and requesting or interpellation from Petroleum Minister. In the framework of general rules, Parliament can be aware of petroleum contracts and can monitor on them. According to the law on Parliament's monitoring on the conclusion of contracts by administrative organs, in the case that financial volume of an petroleum contract is higher than US\$20 million, the government is obliged to inform Planning and Budgeting Commission and Energy Commission of the Parliament on the conclusion of petroleum contracts and their steps. Additionally, in the case that petroleum contract involves commitments over five years; the government should submit a confidential version of the contract to Parliament (Petroleum Law Modification, 1987). By modifying the 
petroleum law, Parliament showed that it can use all its legal capacities granted by the Constitutional Law.

\section{Law and Regulations}

Constitutional Law, Petroleum Law (1974), Petroleum Law (1987), The Law to Modify Petroleum Law (2011), The Law of NIOC Association, Bill on Establishing Petroleum Ministry, the Supplementary Bill on The Law of Establishing Petroleum Ministry, the Law on Encouraging and Supporting Foreign Investment (2002), The Law on Parliament's Monitoring on Conclusion of Contracts by Administrative Organs (2002), The law on allowing NIOC to implement designs to explore, develop and operate petroleum and gas fields in the Caspian Sea (2000), Bill of Law of Petroleum Ministry Act (2011).

\section{References}

[1] Amani Mahmood (2010). Petroleum and Gas International Contract Law, Tehran, Imam Sadegh Publications.

[2] Carreau Dominique (1981). Droit International Public, Les Cours de Droit.

[3] Degan V.D. (1997). Sources of International Law, Netherlands, Kluwer Law.

[4] EL- Khosheri Ahmed S., Tarek F. Riad, The Law Governing a New Generation of Petroleum Agreements: Changes in the Arbitration Process, ICSID Review 1(2)(1986) 257- 288.

[5] Fayazbakhsh Marjaneh (2010). Studying Different Ways of International Contracts in Petroleum and Gas Upstream Projects (By Emphasis on Article 14 of the Fourth Development Plan), M. A. Dissertation, Payam Noor University.

[6] Fitzmaurice M., Elias O. (2005). Contemporary Issues in the Law of Treaties, Netherlands, Eleven International Publishing.

[7] Haddadi Mahdi, The Status of Agreements in Simplified Form in Iranian Laws, Journal of Qom Higher Education Complex 4(14) (2002) 113-151.

[8] Klabbers Jan (1998). The Concept of Treaty in International Law, Netherlands, Kluwer Law.

[9] Mir Abbassi, Seyed Bagher .(1997). Public International Laws, Tehran, Dadgostar Publications.

[10] Mostafavi Seyed Mostafa, Amani Masoud, The Nature of Petroleum International Contracts, Islamic Research Journal 3 (2008).

[11] Parliament Research Center (2007). Repot of Review of the Performance of Petroleum Ministry in Upstream and Downstream Petroleum and Gas Affairs in the $3^{\text {rd }}$ and $4^{\text {th }}$ Development Plans. 
[12] Saber Mohammad Reza (2010). Buyback in Petroleum and Gas Upstream Section, Tehran, Dadgostar Publications.

[13] Shiravi Abdulhussein (2010). International Trade Law, Tehran, SAMT Publications.

[14] Shiravi Abdulhussein, Ebrahimi Seyed Nasrollah, Exploration and Development of Iran Oilfields through Buyback, Natural Resources Forum 30 (2006) 199-206. 